\title{
A EUROPE-WIDE EXPERIMENT FOR ASSESSING THE IMPACT OF GENOTYPE-ENVIRONMENT INTERACTIONS ON THE VITALITY AND PERFORMANCE OF HONEY BEE COLONIES: EXPERIMENTAL DESIGN AND TRAIT EVALUATION
}

\author{
Cecilia Costa ${ }^{1 *}$, Ralph Büchler ${ }^{2 *}$, Stefan Berg ${ }^{3 *}$,
}

Malgorzata Bienkowska ${ }^{*}$, Maria Bouga ${ }^{5}$, Dragan Bubalo ${ }^{6}$,

Leonidas Charistos ${ }^{7}$, Yves Le Conte ${ }^{8 *}$, Maja Drazic9,

Winfried Dyrba ${ }^{10 *}$, Janja Fillipi ${ }^{11}$, Fani Hatjina ${ }^{7 *}$,

Evgeniya Ivanova ${ }^{12}$, Nikola Kezic ${ }^{6 *}$, Hrisula Kiprijanovska ${ }^{13}$,

Michalis Kokinis ${ }^{14}$, Seppo Korpela ${ }^{15 *}$, Per Kryger ${ }^{16 *}$,

Marco Lodesani ${ }^{1}$, Marina Meixner ${ }^{2}$, Beata Panasiuk ${ }^{4}$,

Hermann Pechhacker ${ }^{17 *}$, Plamen Petrov ${ }^{18 *}$, Eugenia

Oliveri ${ }^{19}$, Lauri Ruottinen ${ }^{15}$, Aleksandar Uzunovi3*, Giacomo Vaccari ${ }^{1}$, Jerzy Wilde ${ }^{20 *}$

${ }^{1}$ CRA-API, Bee and Silkworm Research Unit, Via di Saliceto 80, 40128 Bologna, Italy

${ }^{2}$ LLH, Bee Institute, Erlenstrasse 9, 35274 Kirchhain, Germany

${ }^{3}$ Bayerische Landesanstalt für Weinbau und Gartenbau, Bee Division, An der Steige 15, 97209 Veitshöchheim, Germany

${ }^{4}$ Research Institute of Horticulture, Apiculture Division, 24-100 Pulawy, Poland

${ }^{5}$ Agricultural University of Athens, Laboratory of Agricultural Zoology and Entomology, 75 Iera Odos St., Athens 11855 Greece

${ }^{6}$ Faculty of Agriculture, University of Zagreb, Svetosimunska 25, 10000 Zagreb, Croatia

${ }^{7}$ Hellenic Institute of Apiculture (N.AG.RE.F.), N. Moudania, Greece

${ }^{8}$ INRA, UMR 406 Abeilles et Environnement, Laboratoire Biologie et Protection de l'abeille, Site Agroparc, Avignon, France

${ }^{9}$ Croatian Agricultural Agency, Ilica 101, 10000 Zagreb, Croatia

${ }^{10}$ Bee Breeding Centre Bantin, Dorfstrasse 50, 19246 Bantin, Germany

${ }^{11}$ The University of Applied Sciences "Marko Marulic" in Knin, Knin, Croatia

${ }^{12}$ Department of Developmental Biology, University of Plovdiv, Bulgaria

${ }^{13}$ Faculty for Agricultural Science and Food, bul. Aleksandar Makedonski b.b., 1000 Skopje, Republic of Macedonia

${ }^{14}$ Veterinary Centre of Vasilika, Region of Central Macedonia, Greece

${ }^{15}$ MTT, Agrifood Research Finland, 31600 Jokioinen, Finland

${ }^{16}$ University of Aarhus, DJF, Research Centre Flakkebjerg, 4200 Slagelse, Denmark

${ }^{17}$ Austrian Carnica Association, Sulzbach 1, 3293 Lunz am See, Austria

${ }^{18}$ Agricultural University of Plovdiv, 12, Mendeleev Str, Plovdiv 4000, Bulgaria

${ }^{19}$ University of Palermo, Department of Agro-Environmental Systems,

Viale delle Scienze, Edificio 4, 90128 Palermo, Italy

${ }^{20}$ Apiculture Division, Warmia and Mazury University, Sloneczna 48, 10-710 Olsztyn, Poland

E-mail: cecilia.costa@entecra.it

Stars (*) indicate local coordinators per country or location.

Authors after the first are listed in alphabetical order. 


\section{$\mathrm{S} u \mathrm{~m}$ m a r y}

An international experiment to estimate the importance of genotype-environment interactions on vitality and performance of honey bees and on colony losses was run between July 2009 and March 2012. Altogether 621 bee colonies, involving 16 different genetic origins of European honey bees, were tested in 21 locations spread in 11 countries. The genetic strains belonged to the subspecies A. m. carnica, A. m. ligustica, A. m. macedonica, A. m. mellifera, A. m. siciliana. At each location, the local strain of bees was tested together with at least two "foreign" origins, with a minimum starting number of 10 colonies per origin. The common test protocol for all the colonies took into account colony survival, bee population in spring, summer and autumn, honey production, pollen collection, swarming, gentleness, hygienic behaviour, Varroa destructor infestation, Nosema spp. infection and viruses. Data collection was performed according to uniform methods. No chemical treatments against Varroa or other diseases were applied during the experiment. This article describes the details of the experiment set-up and the work protocol.

Keywords: genotype-environment interactions, honey bees, vitality, performance, bee subspecies, methodology.

\section{INTRODUCTION}

Recent years have seen continuing efforts to gain insight into understanding the phenomenon of honey bee colony losses which is affecting the beekeeping world (Neumann and Carreck, 2010) and the environment, due to the pollination value of honey bees (Aizen and Harder, 2009; Gallai et al., 2009; Potts et al., 2010). Many recent studies have investigated possible causes - while no agreement on a single culprit has been achieved there is widespread consensus that the phenomenon is multifactorial (Higes et al., 2006; CoxFoster et al., 2007; Desneux et al., 2007; Chauzat et al., 2009; de Miranda et al., 2010; de Miranda and Genersch 2010; Johnson et al., 2009; Nguyen et al., 2009; Rosenkranz et al., 2009; vanEngelsdorp and Meixner, 2010).

On an international level, the European Science Foundation is currently funding a network of scientists who collaborate on different aspects of bee health: COLOSS (Prevention of Colony Losses), COST (European Cooperation in Science and Technology) Action FA 0803 (started in 2008 - ending in 2012). Within this network, Working Group 4 (WG4) focuses on diversity and vitality of honey bee colonies. Our working hypothesis is based on the assumption that the health of honey bee colonies cannot be understood without considering the genetic variability of honey bee populations and their adaptation to regional environmental factors, such as climate, vegetation and prevailing diseases. The evolution of beekeeping as a cultural practice and as a profession (Crane, 1990) means that the natural process of adaptation can be influenced by the beekeeper, and the development of certain techniques may ultimately reduce colony vitality, i.e., their success in adapting to given environmental circumstances. In the past 50 years, selective breeding of honey bees has considered traits of major apicultural interest, such as honey production, temperament, swarming tendency and quietness on the comb. Technical recommendations based on these traits were published in 1972 by Ruttner and are currently widely accepted as a standard breeding protocol on a European level. There is however an increasing urge towards the selection of disease-resistant stock, due to the decreasing efficacy of varroa-control products, the problem of residues in hive products, the increase of organic production methods and the image of honey as a natural product. This has resulted in the development of several regional projects which introduce vitality criteria into breeding programs, while maintaining the traditional traits described by Ruttner (1972), Garrido et al. (2005), Büchler et al. $(2007,2008)$. These projects are based on the fact that the development of natural resistance against parasites has 
been well characterized in the case of Varroa destructor, where several reports document the survival of colonies in the absence of any treatment (Koeniger et al., 1995; Rinderer et al., 2001; Büchler et al., 2002, 2008; Fries and Bommarco, 2007; Le Conte et al., 2007; Seeley, 2007). Resistance of honey bees against parasitic mites has also been demonstrated in selection programs that focused on behavioural strategies enabling the bees to limit the growth of the mite population (Wilde and Koeniger, 1992a and 1992b; Wilde, 1994; Siuda et al., 1996; Spivak, 1996; Harris and Harbo, 2000; Spivak and Reuter, 2001; Ibrahim and Spivak, 2006; Harris, 2007).

Europe is home to 10 of the 27 currently existing honey bee subspecies, many of which have been subjected to sometimes intense pressures resulting from human activities, such as breeding strategies and intensive land use (Meixner et al., 2010). These honey bee populations represent an important resource for breeding disease and stress resistant strains. Indeed, anecdotal evidence suggests that locally adapted strains of bees suffer less from elevated losses than non native bees.

We established the working hypothesis that one important factor contributing to colony losses is the use of maladapted honey bees, either by beekeepers using genetic stock with insufficient vitality, or by using stock that is not well adapted to locally prevailing environmental conditions. To evaluate this hypothesis, and to elucidate interactions between genotype and environment in honey bees, we conducted a common experiment, where research teams from 11 European countries evaluated the performance of a total of 621 honey bee colonies from 16 different genetic origins in 21 different test apiaries.

In this paper we provide information on the structure of this experiment and setup of the colonies, the methods used for colony management, and all details for the assessment of traits. Thus, this paper will provide the basis for several future publications focusing on the analysis of specific results of the experiment, highlighting different aspects such as survival and population development of the experimental colonies, analysis of behaviour, occurrence of diseases and genetic analyses.

The ultimate aim of our group is to improve honey bee health by developing and disseminating comprehensive breeding strategies that include colony vitality and the conservation of locally adapted populations.

\section{METHODOLOGY}

\section{General design of the experiment}

The experiment included colonies from 16 different genetic origins and took place in 21 bee yards in 11 European countries (Fig. 1), managed by 15 partners. The genetic strains belonged to the subspecies A. m. carnica, A. m. ligustica, A. m. macedonica, A. m. mellifera, A. m. siciliana. Apart from A. m. siciliana, all the other subspecies were present in several different strains characterized by area of origin. The chosen genetic origins included both commercially successful strains selected for traditional favourable traits such as high honey yield and gentleness, and subspecies close to extinction managed by few beekeepers or part of conservation programs.

At each location the local strain of bees was tested together with at least two "foreign" origins, with a minimum starting number of 10 colonies per origin (Tab. 1). Each of the origins tested at 2 to 8 locations. with the exception of the locations in Bulgaria and Macedonia which were distributed in 3 smaller apiaries with different environmental conditions.

\section{Setting up the experiment}

Queens from the different origins were delivered by hand or by express mail to the allocated partners, and were accompanied by TRACES certificates, according to EU Council Directive 92/65/EEC of 13 July 1992 "laying down animal health requirements governing trade in and imports into the Community of animals, 


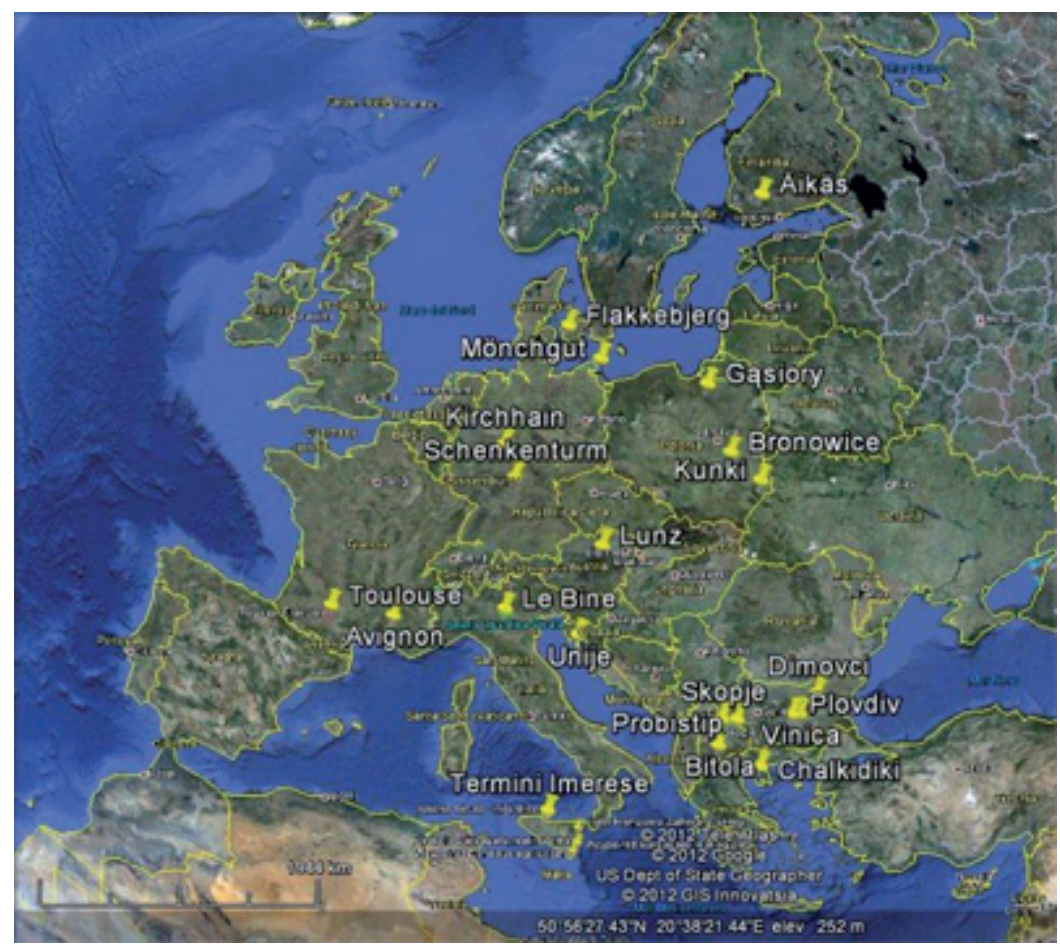

Fig. 1. Location of test apiaries involved in the experiment.

semen, ova and embryos not subject to animal health requirements laid down in specific Community rules referred to in Annex A (I) to Directive 90/425/EEC".

In the summer and autumn of 2009 , new colonies were uniformly set up at each test location (starting from package bees or brood nuclei), and queens of the different strains were introduced. Most of the queens belonging to strains originating from breeding programs were sisters mated under the same (controlled) conditions. Queen introduction was completed in October 2009.

Managing the colonies in the experiment

- Within testing apiaries colonies were managed with uniform methods, while taking care that each colony was allowed to develop according to its need, for example in terms of providing foundations and supers. All operations were recorded in detail.
- Prevention of swarming, when necessary, was achieved by use of temporal queen nucs, in such a way that a continuous bee population and infestation development was maintained. Colonies which swarmed remained in the test group with the daughter queen (naturally mated in the test yard) and the event was noted. Special drone traps in front of the hive entrances were used in some locations to prevent "genetic pollution" of the environment by non-autochthonous drones. In the locations in question, the traps were applied to all colonies in the apiary (local race included).

- In some locations, complete brood removal combined with a trapping comb was carried out as a measure to limit mite and brood diseases and to ensure longer survival of the test colonies, as no other Varroa treatment was performed. The time frame was just after the summer census, 10-14 days before the end of the last honey harvest (in most locations this occurs during the 1st week of July). 


\begin{tabular}{|c|c|c|c|c|c|c|c|c|c|c|c|c|c|c|c|c|c|c|c|c|c|}
\hline \multirow{2}{*}{\multicolumn{22}{|c|}{$\mathbb{D}$}} \\
\hline & & & & & & & & & & & & & & & & & & & & & \\
\hline 氙 言言 & 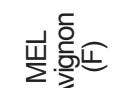 & & & & & & 2 & & & & $\wedge$ & ம & & & & & & & & & \\
\hline 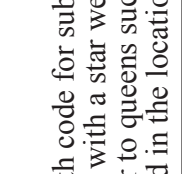 & 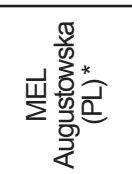 & & & & & & & & & $\nabla$ & $F$ & & & & & & & & & $r$ & \\
\hline 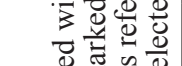 & $\frac{0}{s}$ & 우 & & & & & o & 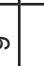 & & & & & & 으 & & m & $m$ & $m$ & & & \\
\hline 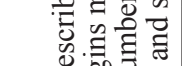 & 捠采 & & $\forall$ & m. & $\nabla$ & 으 & & & & & & & ه & & & + & $m$ & 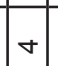 & & & \\
\hline 过 & 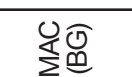 & & $\nabla$ & + & $m$ & & & & & & の & & 으 & & & & & & & \% & \\
\hline 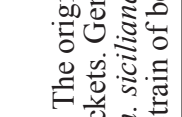 & 它离离 & & & & & & & & & & & & 으 & 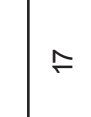 & $\stackrel{9}{\square}$ & & & & & & \\
\hline . & 兄 ${ }_{\text {䍃 }}^{*}$ & & & & & 은 & & & & & & & & 우 & $\infty$ & & & & & & \\
\hline 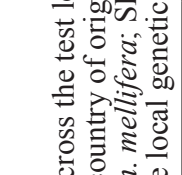 & 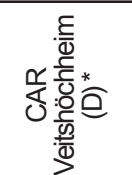 & & & & & & & & $F$ & & & & 으 & & & & & & $\cong$ & & \\
\hline 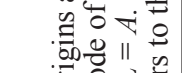 & 孚通志 & 우 & & & & ه & $\approx$ & 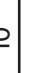 & & & & & & & & & & & & ๑) & \\
\hline 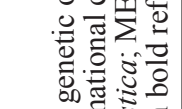 & 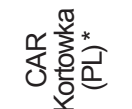 & 으 & $\diamond$ & $\diamond$ & $\sim$ & & $?$ & & & & & 으 & & & & & & & & $=\cong$ & \\
\hline 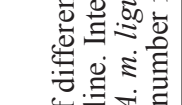 & 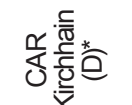 & & & & & & $?$ & & & & & & & $?$ & & & & & & $=$ & \\
\hline 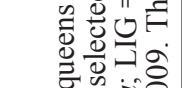 & 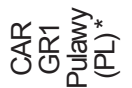 & & $\theta$ & & $\nabla$ & & & & $?$ & & & & & & & & & & & s & \\
\hline 过 & 兴众 & & & & & & & & & & & & & $?$ & & m & $\nabla$ & $m$ & $\wedge S$ & $\simeq$ & \\
\hline 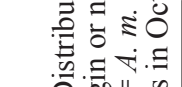 & 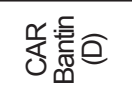 & & & & & 으 & 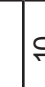 & $?$ & $?$ & & & ه & & ๑) & & & & & & & \\
\hline 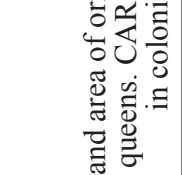 & & 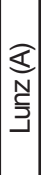 & 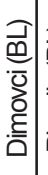 & 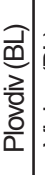 & 胥: & 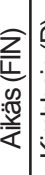 & 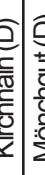 & 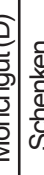 & 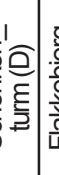 & 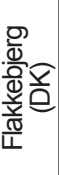 & 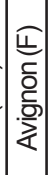 & 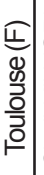 & 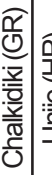 & 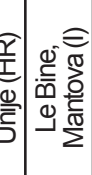 & 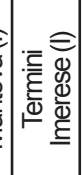 & $=\frac{2}{2}$ & $\begin{array}{l}\frac{8}{2} \\
: 0 \\
: \frac{0}{0} \\
\frac{0}{0} \\
0\end{array}$ & $\left|\begin{array}{l}\frac{8}{2} \\
\frac{0}{2} \\
\frac{0}{2} \\
\omega\end{array}\right|$ & 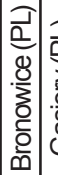 & 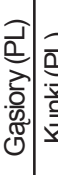 & a) \\
\hline
\end{tabular}


Timing of brood removal was also determined by considering that at least 2 additional brood cycles before overwintering should be possible.

- Supply of sugar candy or syrup was noted.

- In some locations, colonies in danger of collapsing were withdrawn from the apiary (or immediately treated and removed) to prevent domino effects. Threshold values of $>10 \%$ Varroa infestation of bee samples and $<5000$ adult bees were used (Büchler et al., 2008).

\section{Treatments against diseases}

In some locations an initial treatment against Varroosis with oxalic or lactic acid had to be performed in the fall of 2009 to reduce high mite loads at the beginning of the experiment. Apart from this, no chemical treatments against mites or other diseases were applied in the course of the experiment. Complete brood removal in the summer was the only treatment option used to reduce mite loads. When performed, it involved all test colonies in the apiary.

\section{Evaluation of colony vitality and performance}

Colonies were assessed for the traditional selection traits: honey yield, gentleness and swarming tendency. In addition, the test parameters included traits potentially linked to vitality, such as colony development, feed balance and pollen stores, overwintering ability (estimated on the basis of colony size) and disease tolerance parameters, such as mite infestation level, hygienic behaviour and the occurrence of other diseases. Queen survival and health status of the colony were noted at every hive inspection. Superseded queens were not excluded or exchanged, but all queens were individually marked in order to document the sequence of generations.

A complete census for each experimental colony was performed in spring, summer and autumn, from autumn 2009 until spring 2012. The time of the census in each location was determined according to the phenological stage principles, as described below.
1) Spring census: performed during blossoming (within 3 weeks) of the first plentiful pollen producing plant, so as to coincide with the beginning of main brood production. In Central - Northern Europe willow (Salix spp.) was used as reference, in Southern Europe reference blooming was almond (Prunus amigdalus) or hazel (Corylus avellana).

2) Summer census: the suggested time frame was 10-14 days before end of last honey harvest (time range between midJune and mid-July). This census was performed just before the complete brood removal, if this was performed (see below).

3) Autumn census: performed at end of the brood season (time range between midSeptember and mid-November).

At each census the test parameters relating to colony development were measured and registered according to the methods and units described below. Additional measurements of disease parameters were also taken between the censuses.

\section{Measurements of test parameters:}

Several training sessions were held to harmonise measurement of the test parameters among all partners involved, at the beginning and during the experiment. A summary of measurement methods and units is given in Table 2 .

Colony size was determined by estimating the adult bee population and the amount of brood present in the colony. In accordance with the "Liebefeld method" (Imdorf et al., 1987) the adult bee population was assessed by visual estimation of the percentage of comb surface densely covered by bees. This was carried out sequentially for both sides of each frame in each hive box. Each percentage value was then transformed into bee surface in square $\mathrm{dm}$ according to the size of frame used and multiplied with 130 bees per square dm, so that a total number of adult bees per colony was obtained.

A self evaluation test was run by each participant, in order to determine the accuracy of his/her measurements: the estimations of the adult bee population 
(as described above) of a strong, weak and medium colony were compared to the number of adult bees of the same colonies obtained by weighing the bees. This was achieved by shaking each comb with adult bees into a swarm box and then weighing it, and adding the number of returning bees to the hive after 10 minutes (number visually assessed). The two kinds of measurements were performed on the same day. The result was used to determine the deviation of visual estimation from the more accurate measurement by weighing. The resulting correction factor was applied when the deviation was high $(>10 \%)$. The test was performed at least once for each participant.

To assess the amount of capped and uncapped brood (which were considered together) the brood surface was measured by use of an empty frame consisting of a $10 \times 10 \mathrm{~cm}$ grid. Each $10 \times 10 \mathrm{~cm}$ includes approximately 418 brood cells (the number may vary according to the kind of foundation used - each partner checked the number of cells accordingly) and this value was used to obtain the total number of brood cells present in the colony. In cases where different measurement methods were already routinely used by the local testing team (e.g. Liebefeld method), it was decided that the traditional method could be applied to the benefit of accuracy from experience and speed of estimation.

\section{Colony weight and honey yield}

Colony weight was assessed in most locations by weighing the hive with scales at each census. Harvested honey was weighed and any supplementary feeding or placement/removal of honey combs was also noted. In this way the feed balance of the colony, i.e. how much honey was consumed in relation to the honey gained during the season, could be calculated. In some cases the amount of honey present in the hive was estimated only in autumn and spring in order to calculate the food consumption during the winter.

The amount of pollen in the colony was evaluated by assigning a score on a 1-4

Table 2 .

Test parameters

\begin{tabular}{|c|c|c|c|}
\hline Parameter & Value unit & Measurement method & Measurement time \\
\hline Adult bee population & Number of bees & $\begin{array}{c}\% \text { of comb covered } \\
\text { by bees }\end{array}$ & $\begin{array}{l}\text { Spring, summer, } \\
\text { autumn census }\end{array}$ \\
\hline Brood quantity & $\begin{array}{l}\text { Number of capped and } \\
\text { uncapped brood cells }\end{array}$ & $10 \mathrm{~cm}^{2}$ grid & $\begin{array}{l}\text { Spring, summer, } \\
\text { autumn census }\end{array}$ \\
\hline Honey stores & $\mathrm{Kg}$ & Field hive scale & $\begin{array}{l}\text { Spring, summer, } \\
\text { autumn census }\end{array}$ \\
\hline Pollen stores & 1-4 Score & $\begin{array}{c}\text { According to } \% \text { of } \\
\text { brood area occupied: } \\
4=>10 \% \\
3=5-10 \% \\
2=1-5 \% \\
1=<1 \% \\
\end{array}$ & $\begin{array}{l}\text { Spring, summer, } \\
\text { autumn census }\end{array}$ \\
\hline Honey yield & $\mathrm{Kg}$ & $\begin{array}{c}\text { Net weight of } \\
\text { extracted honey }\end{array}$ & $\begin{array}{l}\text { Whenever honey } \\
\text { is extracted }\end{array}$ \\
\hline Hygienic behaviour & $\%$ removed dead brood & Pin Test & $\begin{array}{l}2 \text { or } 3 \text { times during } \\
\text { active season }\end{array}$ \\
\hline Natural mite fall & $\mathrm{N}^{\circ}$ fallen mites per day & $\begin{array}{l}\text { Sticky sheets on } \\
\text { bottom board }\end{array}$ & $\begin{array}{l}\text { During 2-3 weeks } \\
\text { in spring }\end{array}$ \\
\hline Swarming tendency & 1-4 Score & $\begin{array}{c}\text { 4= no SW. T. } \\
\text { 3= only slight SW. T. } \\
\text { 2= moderate SW. T. } \\
\text { 1= strong SW. T. }\end{array}$ & $\begin{array}{l}\text { Spring census, and } \\
\text { whenever colonies } \\
\text { are checked during } \\
\text { swarming season } \\
\end{array}$ \\
\hline Gentleness & 1-4 Score & $\begin{array}{c}=\text { extremely gentle } \\
3=\text { very gentle } \\
2=\text { not very gentle } \\
1=\text { not gentle at all }\end{array}$ & $\begin{array}{l}\text { Spring, summer, } \\
\text { autumn census }\end{array}$ \\
\hline
\end{tabular}


scale, where in general: $4=$ exceptional; $3=$ good; $2=$ satisfactory; $1=$ unsatisfactory. The score was assigned according to the amount of pollen relative to the quantity of brood present at that moment: $4=$ pollen stores are present in an area representing more than $10 \%$ of the total brood area (e.g. area corresponding to 2 combs filled with pollen in a 20 brood comb Langstroth hive); $3=$ pollen stores are present in an area representing $5-10 \%$ of total brood area; $2=$ pollen stores are present in an area representing $1-5 \%$ of total brood area; $1=$ pollen stores are absent or present in an area representing less than $1 \%$ of total brood area.

The behavioural traits traditionally considered in breeding schemes were also assessed, according to the Apimondia International Breeding Recommendations (Ruttner, 1972):

Swarming tendency: judged according to four-point system (at the end of the testing season the lowest registered score was assigned)

- 4 points $=$ the colony has shown no swarming tendency whatsoever for the entire season (has not constructed any queen cells)

- 3 points $=$ queen cells were found in a routine examination. After the necessary expansion (additional supers) and the breaking up of the queen cells, no more queen cells were constructed.

- 2 points $=$ queen cells were repeatedly found in routine examinations and swarming was difficult to control.

- 1 point $=$ the test colony swarmed or swarming could be prevented only by extensive intervention (e.g., interim nucleus)

Queen cells for a natural supersedure of the queen are not considered swarm cells.

Gentleness: judged according to the four-point system (at the end of the testing season the average score was assigned)

- 4 points $=$ no protection and no smoke necessary to avoid stings

-3 points $=$ no protection and only a little smoke necessary, no stings
- 2 points $=$ much smoke and protection (veil, gloves) necessary to avoid stings and in order to be able to work unimpeded

- 1 point $=$ work without a lot of smoke, face protection, and gloves not possible; stings occur even at a great distance from the apiary

Calmness on the comb: measurement of this trait was optional and was judged according to the four-point system (at the end of the testing season the average score was assigned)

- 4 points $=$ Bees stick to their combs "like fur" without any notable reaction to being handled

-3 points $=$ Bees are moving, but do not leave their combs during treatment.

-2 points $=$ Bees partly leave their combs and cluster in the edges of frames and supers

- 1 point $=$ Bees nervously leave the combs, run out of the supers and cluster inside or outside the hive

Hygienic behaviour of the colony was assessed by means of the "pin test": 50 cells containing young pupae (white or reddish eyes) were pierced (killed) with a fine insect pin (entomological pin size $\mathrm{n}^{\circ} 2$, diameter $=0.45 \mathrm{~mm}$ ) and their removal by adult bees was estimated after a certain length of time. Overall, the highest discriminatory power of the test is reached when on average 50\% of the pupae are removed. In the first year (2010), the time interval between piercing the cells and checking the removal was adapted to the average removal response of the test population. The recommendation was to perform first check after 8 hours, and to check again after 16 hours if 50\% average removal was not reached. The test was repeated 2-3 times during the active season. In 2011 it was decided to uniformly score after 8 hours to obtain better comparability across locations.

Natural mite fall was measured over 3-4 weeks during the first main spring pollen producing bloom (willow, hazel, almond) as a phenological standardization for different climatic regions. Mites fallen onto a sticky board were counted every few days for $\sim 3$ weeks. The parameter was 
expressed as daily mite fall. These data could be used together with the infestation level of adult bees at a given point in the summer to describe Varroa population development.

Collection and analyses of samples for disease monitoring:

- Nosema infection level: from each test colony 60 forager bees were collected for Nosema spp. infection level. To ensure harmonized sampling procedure across locations bees were collected from the outer frames. Subsequent detection and count of Nosema spp. spores was performed following the OIE procedure. The reported information for each colony was number of spores per bee.

- Nosema species determination: 30 forager bees per colony from at least 3 colonies per apiary were sampled and immediately frozen for discrimination of Nosema species ( $N$. apis or $N$. ceranae).

- Varroa infestation level: in each active season sampling bees for determination of Varroa destructor infestation levels was performed monthly, starting in June and repeated until the autumn. At least $30 \mathrm{~g}$ of bees were collected from honey combs of the uppermost box, or from outer frames when no honey box was present. For the analysis, the net weight of the bees was measured. The bees were then floated in soapy water ( $\sim 60 \mathrm{ml}$ of dish-washing detergent in 1 litre water) for about 30 minutes, after having been shaken for at least 1 minute. Then the mites were washed off from the bees and separated by the use of a double sieve (e.g. a honey sieve) (Rinderer et al., 2004). Data were expressed as $n^{\circ}$ of mites per 10 $\mathrm{g}$ of bees.

- Virus detection: samples of about 50 live adult bees were collected from outer frames for virus analyses at the end of the active season (September-October) and again in spring. The samples were immediately frozen $\left(-20^{\circ} \mathrm{C}\right.$ or $\left.-80^{\circ} \mathrm{C}\right)$ until RNA extraction.

- Subspecies discrimination: about 3 young bees per colony were collected from the brood-nest area and preserved in $96 \%$ ethanol for confirmation of subspecies identification of each genetic origin used in the experiment. Furthermore, these bees were used for comparison and validation of the following subspecies discrimination methods: morphometric, mitochondrial DNA, microsatellite analyses.

\section{Environmental conditions}

Data on meteorological conditions (mean, minimum and maximum daily temperature, rain fall and humidity) were collected for all experimental locations.

\section{Data collection}

An online spreadsheet was set up and made accessible to all participants on the website of Google Documents. Thus, all data collected could be inserted directly by individual members of the group. The file was developed with a conditional formatting tool in order to avoid any technical or writing mistakes.

\section{Acknowledgments}

The team from the Republic of Macedonia wishes to thank the beekeepers Dico Dimkovski, Ivan Dodevski and Ilija Petrovski, on whose apiaries the experiment was conducted, for their cooperation and understanding. The Italian team wishes to thank beekeeper Carlo Amodeo and the Italian Food, Forestry and Agriculture Policies Ministry (MIPAAF) which provided financial support through the project APENET. WG4 wishes to thank the referees and JAS scientific committee for their valuable contribution. Gratitude also to Anglotranslate for English language revision.

\section{REFERENCES}

Aizen M. A., Harder L. D. (2009) - The global stock of domesticated honey bees is growing slower than agricultural demand for pollination. Current Biology, 19: 915-918.

Büchler R., Berg S., Kezic, N., Pechhacker, H., Van Praagh, J., Bubalo D., Ritter W., Bienefeld K. (2002) - Survival test without treatment against varroatosis - the island project in Croatia. Apidologie, 33: 493-494. 
Büchler R., Garrido C., Bienefeld K., Ehrhardt K. (2007) - German honey bee selection program on disease tolerance. Proceedings $40^{\text {th }}$ International Apicultural Congress, Melbourne, Australia, 399.

Büchler R., Garrido C., Bienefeld K., Ehrhardt K. (2008) - Selection for Varroa tolerance: concept and results of a long-term selection project. Apidologie, 39(5): 598.

Büchler R., Berg S., Le Conte Y. (2010) - Breeding for resistance to Varroa destructor in Europe. Apidologie, 41(3): 393-408.

Chauzat M. P., Carpentier P., Martel A. C., Bougeard S., Cougoule N., Porta P., Lachaize J., Madec F., Aubert M., Faucon J. P. (2009) - Influence of pesticide residues on honey bee (Hymenoptera: Apidae) colony health in France. Environ. Entomol. 38: 514-523.

Crane E. (1990) - Bees and Beekeeping. Science, Practice and World resources. Cornell University Press, Ithaca, New York.

Cox-Foster D. L., Conlan S., Holmes E. C., Palacios G., Evans J. D., Moran N. A., Quan P. L., Briese T., Hornig M., Geiser D. M., Martinson V., vanEngelsdorp D., Kalkstein A. L., Drysdale A., Hui J., Zhai J., Cui L., Hutchinson S. K., Simons J.F., Egolm M., Pettis J. S., Lipkin W. I. (2007) - A metagenomic survey of microbes in honey bee colony collapse disorder. Science, 318: 283-287.

De Miranda J. R., Genersch E. (2010) Deformed Wing Virus. J. . Invertebr. Pathol., 103 Suppl.1: 48-61.

De Miranda J. R., Cordoni G., Budge G. (2010) - The Acute-Bee-Paralysis KashmirBee-Virus Israeli - Acute - Paralysis - Virus complex. J. Invertebr. Pathol., 103 Suppl. 1: 30-47.

Desneux N., Decourtye A., Delpuech J. M. (2007) - The sublethal effects of pesticides on beneficial arthropods. Annu. Rev. Entomol., 52, 81-106.

Fries I., B ommarco R. (2007) - Possible hostparasite adaptations in honey bees infested by Varroa destructor mites. Apidologie, 38(6): 525-533.
Gallai N., Michel Salles J. M., Settele J., Vaissière B. E. (2009) Economic valuation of the vulnerability of world agriculture confronted with pollinator decline. Ecol. Econom., 68(3): 810-821. DOI: 10.1016/j.ecolecon.2008.06.014

Garrido C., Büchler R., Bienefeld K., Ehrhardt K. (2005) - Breeding for tolerance against Varroosis factors influencing colony survival without treatment in a long-term survey. Proceedings of $39^{\text {th }}$ Apimondia congress, Dublin, 21.-26.08.2005, 76.

Harris J. W. (2007) - Bees with Varroasensitive hygiene preferentially remove miteinfested pupae aged $\leq 5$ days postcapping. J. Apic. Res., 46(3): 134-139.

Harris J. W., Harbo J. R. (2000) - Changes in reproduction of Varroa destructor after honey bee queens were exchanged between resistant and susceptible colonies. Apidologie, 31: 689699. DOI.org/10.1051/apido:2000153

Higes M., Martin R., Meana A. (2006) - Nosema ceranae, a new microsporidian parasite in honeybees in Europe. J. Invertebr. Pathol., 92: 93-95.

Ibrahim A., Spivak M. (2006) - The relationship between hygienic behaviour and suppression of mite reproduction as honey bee (Apis mellifera) mechanisms of resistance to Varroa destructor. Apidologie, 37(1): 31-40. DOI.org/10.1051/apido:2005052

Imdorf A., Buehlmann G., Gerig L., Kilchenmann V., Wille H. (1987) - Überprüfung der Schätzmethode zur Ermittlung der Brutfläche und der Anzahl Arbeiterinnen in freifliegenden Bienenvölkern. Apidologie, 18(2): 137-146.

Johnson R. M., Evans J. D., Robinson G. E., Berenboum M. R. (2009) - Changes in transcript abundance relating to colony collapse disorder in honey bees (Apis mellifera). Proceedings of the National Academy of Sciences, 106(35): 14790-14795.

Koeniger N., Schmidt J., Wilde J., Kefuss J., Ducos de Lahitte J. (1995) - Versuche zur Varroatosetoleranz von Bienen aus Uruquay in Europa. Pszczeln. Zesz. Nauk., 39(1): 121-131. 
Le Conte Y., De Vaublanc G.,
Crauser D., Jeanne F., Rousselle J. C., Bécard J. M. (2007) - Honey bee colonies that have survived Varroa destructor. Apidologie, 38: 566-572.

Martìn-Hernández R., Meana A., Prieto L., Martìnez Salvador A., Garrido-Bailón E., Higes M. (2007) Outcome of colonization of Apis mellifera by Nosema ceranae. Appl. Environ. Microb. 73: 6331-6338.

Meixner M. D., Costa C., Kryger P., Hatjina F., Bouga M., Ivanova E., Büchler R., (2010) - Conserving diversity and vitality for honey bee breeding. J. Apic. Res., 49(1): 85-92.

Neumann P., Carreck N. L. (2010) Honey bee colony losses. J. Apic. Res., 49(1): 1-6. DOI: 10.3896/IBRA.1.49.1.01

Nguyen B. K., Saegerman C., Pirard C., Mignon J., Widart J., Thirionet B., Verheggen F. J., Berkvens D., De Pauw E., Haubruge E. (2009) Does imidacloprid seed-treated maize have an impact on honey bee mortality? J. Econ. Entomol., 102: 616-623.

Potts S. G., Biesmeijer J. C., Kremen C., Neumann P., Schweiger O., Kunin W. E. (2010) - Global pollinator declines: trends, impacts and drivers. Trends in Ecology \& Evolution, 25: 345-353.

Rinderer T. E., De Guzman L. I., Delatte G. T., Stelzer J. A., Lancaster V. A., Kuznetsov V., Beaman L., Watts R., Harris J. W. (2001) - Resistance to the parasitic mite Varroa destructor in honey bees from far eastern Russia. Apidologie, 31: 381-394.

Rinderer T. E., De Guzman L. I., Sylvester H. A. (2004) - Reexamination of the accuracy of a detergent solution for varroa mite detection. Am.Bee J., 144: 560-562.

Rosenkranz P., Aumeier P., Ziegelmann B. (2009) - Biology and control of Varroa destructor. J. Invertebr. Pathol., 103, 96-S119.
Ruttner H. (1972) - Technical recommendations for methods of evaluating performance of bee colonies. In F. Ruttner, Controlled mating and selection of the honey bee Bucharest, Apimondia, pp. 87-92.

Seeley T. D. (2007) - Honey bees of the Arnot forest: a population of feral colonies persisting with Varroa destructor in the northeastern Unites States. Apidologie, 38:19-29.

Siuda M., Wilde J., Koeniger N. (1996) Further Research on Honeybee Breeding with Short Post-capping Periods. Pszczeln. Zesz. Nauk., 40(2): 135-143.

Spivak M. (1996) - Honey bee hygienic behaviour and defence against Varroa jacobsoni. Apidologie, 27: 245-260.

Spivak M., Reuter G. S. (2001) - Varroa destructor infestation in untreated honey bee (Hymenoptera: Apidae) colonies selected for hygienic behaviour. J. Econ. Entomol., 94: 326-331.

vanEngelsdorp D., Meixner M. D. (2010) - A historical review of managed honey bee populations in Europe and the United States and the factors that may affect them. J. Invertebr. Pathol., 103, 80-95.

Wilde J. (1994) - Hodowla pszczół o skróconym okresie postlarwalnym, odpornych na Varroa jacobsoni Oudemans. [Breeding honey bees for short post-capping period resistant to Varroa jacobsoni Oudemans]. Acta Academiae Agriculturae ac Technicae Olstenensis, Zootechnica, Suplementum B 39: $1-43$.

Wilde J., Koeniger N. (1992a) - Breeding for a short post-capping period in Apis mellifera carnica worker brood after initial crossing with Apis mellifera capensis. Apidologie, 23(4): 429-431.

Wilde J., Koeniger N. (1992b) - Selektion auf Verkürzung der Zellverdeckelungsdauer (ZVD) der Arbeiterinnenbrut von Apis mellifera carnica. Annales Universitatis Mariae Curie-Skłodowska, Sectio DD, 47(25): 133-136. 


\title{
OKREŚLENIE WPLYWU INTERAKCJI \\ GENETYCZNO-ŚRODOWISKOWYCH NA WYDAJNOŚĆ \\ I WITALNOŚĆ RODZIN PSZCZELICH W EUROPIE: PROJEKT DOSWIADCZENIA I METODYKA POMIARU CECH
}

\author{
Costa C., Büchler R., Berg S., Bienkowska M., Bouga M., \\ Bubalo D., Charistos L., Le Conte Y., Drazic M., Dyrba W., \\ Fillipi J., Hatjina F., Ivanova E., Kezic N., Kiprjanovska H., \\ Kokinis M., Korpela S., Kryger P., Lodesani M., \\ Meixner M., Panasiuk B., Pechhacker H., Petrov P., \\ Oliveri E., Ruottinen L., Uzunov A., Vaccari G., Wilde J.
}

$\mathrm{S}$ t $\mathrm{r}$ e s z c $\mathrm{z}$ e $\mathrm{n}$ i e

Badania wpływu interakcji genetyczno-srodowiskowych na żywotność pszczół miodnych oraz na straty rodzin pszczelich rozpoczęto w lipcu 2009 roku, a zakończono 31 marca 2012. W ramach międzynarodowych badań obserwowano w 21 pasiekach rozmieszczonych w 11 krajach europejskich, łącznie 621 rodzin pszczelich pochodzących z 16 populacji różnych genetycznie. Były to pszczoły należące do podgatunków: A. m. carnica, A. m. ligustica, A. m. macedonica, A. m. mellifera, A. m. siciliana. W każdej z pasiek porównywano co najmniej 10 rodzin pszczół z populacji lokalnej przynajmniej z dwiema grupami (po 10 rodzin w grupie) populacji „obcych”. Badano następujące cechy: przeżywalność pszczół, liczbę pszczół w rodzinach wiosną, latem i jesienią, wydajność miodową i pyłkową, rojliwość, łagodność, zachowanie higieniczne, stopień porażenia przez Varroa, zakażenie Nosema spp, obecność wirusów. We wszystkich rodzinach doświadczalnych zastosowano zunifikowane metody gospodarki pasiecznej i pomiaru cech. $\mathrm{W}$ okresie doświadczenia $\mathrm{w}$ badanych rodzinach pszczelich nie stosowano żadnych środków leczniczych bez względu na stopień porażenia przez pasożyty czy obecność chorób. W artykule opisano materiał, harmonogram i metodę wykonania badań.

Słowa kluczowe: interakcje genetyczno-środowiskowe, pszczoła miodna, żywotność, wydajność, podgatunki pszczół, metodyka. 